\title{
Intra- and inter-annual changes in the condition factors of three Curimatidae detritivores from Amazonian floodplain lakes
}

\author{
Gisele Batista Correia $^{1,2}$, Flávia Kelly Siqueira-Souza ${ }^{1}$ \& Carlos Edwar de Carvalho Freitas ${ }^{1}$ \\ ${ }^{1}$ Universidade Federal do Amazonas, Faculdade de Ciências Agrárias, Av. General Rodrigo Octávio, \\ 6200 Coroado I, CEP:69077-000, Manaus, AM, Brazil. \\ ${ }^{2}$ Corresponding author: Gisele Batista Correia, e-mail: giselemika@gmail.com
}

CORREIA, G.B., SIQUEIRA-SOUZA, F.K., FREITAS, C.E.C. Intra- and inter-annual changes in the condition factors of three Curimatidae detritivores from Amazonian floodplain lakes. Biota Neotropica. 15(4): e0001. http://dx.doi.org/10.1590/1676-0611-BN-2014-0001

\begin{abstract}
The flood pulse is a key factor that drives the biota of large rivers with adjacent floodplains, but the direction and intensity of its effects are not uniform for all trophic guilds of fish. In this study, we tested the existence of intra- and inter-annual changes in the relative condition factors $(\mathrm{kn})$ of three Curimatidae: Potamorhina altamazonica, Potamorhina latior, and Psectrogaster rutiloides. We used weight and length data from fish that were caught in eight floodplain lakes of the Rio Solimões. These data were from experimental fisheries during each season of the hydrological cycle: flooding, flood, drying, and dry from 2004, 2005, and 2006. In general, there are similar patterns of intra-annual changes for these three species, with the highest estimates of $\mathrm{kn}$ during high water conditions. The lowest values were observed during the drying and dry seasons of 2005, when an extreme drought occurred in the Amazon basin. Higher values were observed during the same seasons in the year post-drought. We hypothesized that these patterns would be explained by the biological characteristics of these species and the effects of intra-annual hydrological changes, mainly the flood pulse effect, and by inter-annual climatic events, which are determined by global climate phenomena. Keywords: Weight-length relationship, Curimatidae, environmental effects, relative condition factor, floodplain lakes.
\end{abstract}

CORREIA, G.B., SIQUEIRA-SOUZA, F.K., FREITAS, C.E.C. Variação intra e interanual do fator de condição de três espécies detritívoras de Curimatidae em lagos de várzea da Amazônia. Biota Neotropica.15(4): e0001. http://dx.doi.org/10.1590/1676-0611-BN-2014-0001

Resumo: O pulso de inundação é considerado um fator chave no direcionamento da biota de grandes rios associados a área de várzea, mas a direção e intensidade dos efeitos do pulso de inundação não são uniformes para todas as guildas tróficas dos peixes. Neste estudo, nós testamos a existência de mudanças intra e interanuais no fator de condição $(\mathrm{Kn})$ de três curimatideos: Potamorhina altamazonica, Potamorhina latior $e$ Psectrogaster rutiloides. Foram usados dados de peso e comprimento de peixes capturados em oito lagos, localizados na planície aluvial do rio Solimões. Estes dados foram obtidos em pescarias experimentais realizadas em quatro fases do ciclo hidrológico: enchente, cheia, vazante e seca nos anos de 2004, 2005 e 2006. Observamos um padrão similar de variação intra-anual para as três espécies, com maiores valores de Kn durante o período de águas altas. O valor mais baixo foi observado no período de vazante e seca em 2005 quando ocorreu um evento de seca extrema na bacia. Valores altos foram observados, durante o mesmo período, no ano posterior a seca. Consideramos que estes padrões são explicados pelas características biológicas das espécies e pelo efeito das mudanças ambientais determinadas pelo efeito do pulso de inundação, além da contribuição de eventos climáticos em escala global.

Palavras-chave: Relação peso-comprimento, Curimatidae, efeitos ambientais, fator de condição relativo, lagos de várzea.

\section{Introduction}

The flood pulse is the environmental phenomenon that drives the biological process in large rivers with adjacent floodplains (Junk et al. 1989), such as rivers in the Amazon Basin. This phenomenon is predictable, and aquatic Amazonian organisms have developed several types of adaptations to survive in this dynamic system, with markedly alternating aquatic-terrestrial phases. In this basin, there is sufficient information to corroborate the statement that ecological and physiological processes, which happen to fish, are determined by changes in the aquatic environment that are regulated by the flood pulse (Junk et al. 1997) from the level of organisms (Val \& Almeida-Val 1995; Soares et al. 2006) to populations (Fernandes 1997) to communities (Tejerina-Garro et al. 1998; Granado-Lorencio et al. 2005; Garcez \& Freitas 2008). These effects should be different for species from different trophic or reproductive guilds. 
However, other climatic phenomena could happen in different temporal scales and intra- and inter-annual changes in environmental conditions should cause detectable effects at the organism level. Below a specific level of intensity, these changes should be buffered by the physiological plasticity inherent to each species. Above this level, these environmental changes could result in detectable changes at the organism level. It is possible that highmagnitude climatic events could also be evident at the population level (Ficke et al. 2007; Freitas et al. 2012).

The parameter $a$ of the weight-length relationship is termed the condition factor (Le Cren 1951) because of its ability to represent fish well-being. There is a consensus that the condition factor is influenced by environmental conditions or physiological or behavioral processes (Froese 2006). For example, food availability or reproductive stages could determine the variability observed in the condition factor.

Curimatidae is a family of toothless freshwater fish with a large geographic distribution in the Neotropics (Vari 1984; 1992; Reis et al. 2003). In the Amazon basin, they are observed mainly in the Central Amazon and in the headwaters of nutrient-rich rivers (Araújo-Lima \& Ruffino 2003). This group is composed almost exclusively of relatively small $(<25 \mathrm{~cm})$ benthopelagic species with diurnal behavior that live in lakes and rivers of white and black waters (Saint-Paul et al. 2000; Siqueira-Souza \& Freitas 2004). Potamorhina altamazonica (Cope 1878), Potamorhina latior (Spix and Aagassiz 1829) and Psectrogaster rutiloides (Kner 1858) are three Curimatidae species, termed "branquinhas," in the Amazon basin. They are short-distance migratory species (AraújoLima \& Ruffino 2003), which have annual migration patterns to breed upriver (Lima \& Araújo-Lima 2004; Granado-Lorencio et al. 2005), and their larvae drift in the main stem of the
Amazonas River (Araújo-Lima 1991). They are detritivores, mainly eating organic material, algae and microorganisms (Mérona \& Rankin-de-Mérona 2004; Pouilly et al. 2004), and could be favored by seasons with high availability of these items in the environment. In an opposite way, seasons with low availability of detritus could be severely adverse to this species group.

In the present study, we analyzed modifications in the condition factor of the species Potamorhina altamazonica, Potamorhina latior and Psectrogaster rutiloides with the aim of identifying the seasons that result in advantageous and disadvantageous environmental conditions for these species, which have the same feeding behavior. These environmental conditions were associated with two temporal scales: intra- and inter-annual effects. Our data include the severe drought of 2005 (Marengo et al. 2008), and we believe that the results of the present study constitute a preliminary insight into the effects of extreme climatic events on Amazonian fish species at the population level.

\section{Material and Methods}

\section{Study Area}

The fish were collected in eight floodplain lakes from 2004 to 2006. These lakes are placed at the banks of a stretch of 400 kilometers of the Rio Solimões, nominally: Baixio ( $03^{\circ} 18^{\prime} 01^{\prime \prime} ; 60^{\circ}$ $05^{\prime} 30^{\prime \prime}$ ), Preto ( $\left.03^{\circ} 20^{\prime} 39^{\prime \prime} ; 60^{\circ} 35^{\prime} 22^{\prime \prime}\right)$, Iauara (03 36' 20";

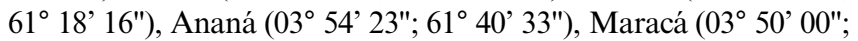
$\left.62^{\circ} 34^{\prime} 00^{\prime \prime}\right)$, Araçá ( $\left.03^{\circ} 46^{\prime} 14^{\prime \prime} ; 62^{\circ} 22^{\prime} 01^{\prime \prime}\right)$, Poraquê (03 $57^{\prime}$

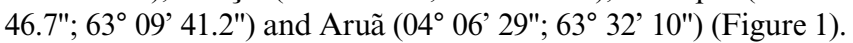
All of these lakes are typical perennial floodplain lakes that remained connected to the main river for most of the year.

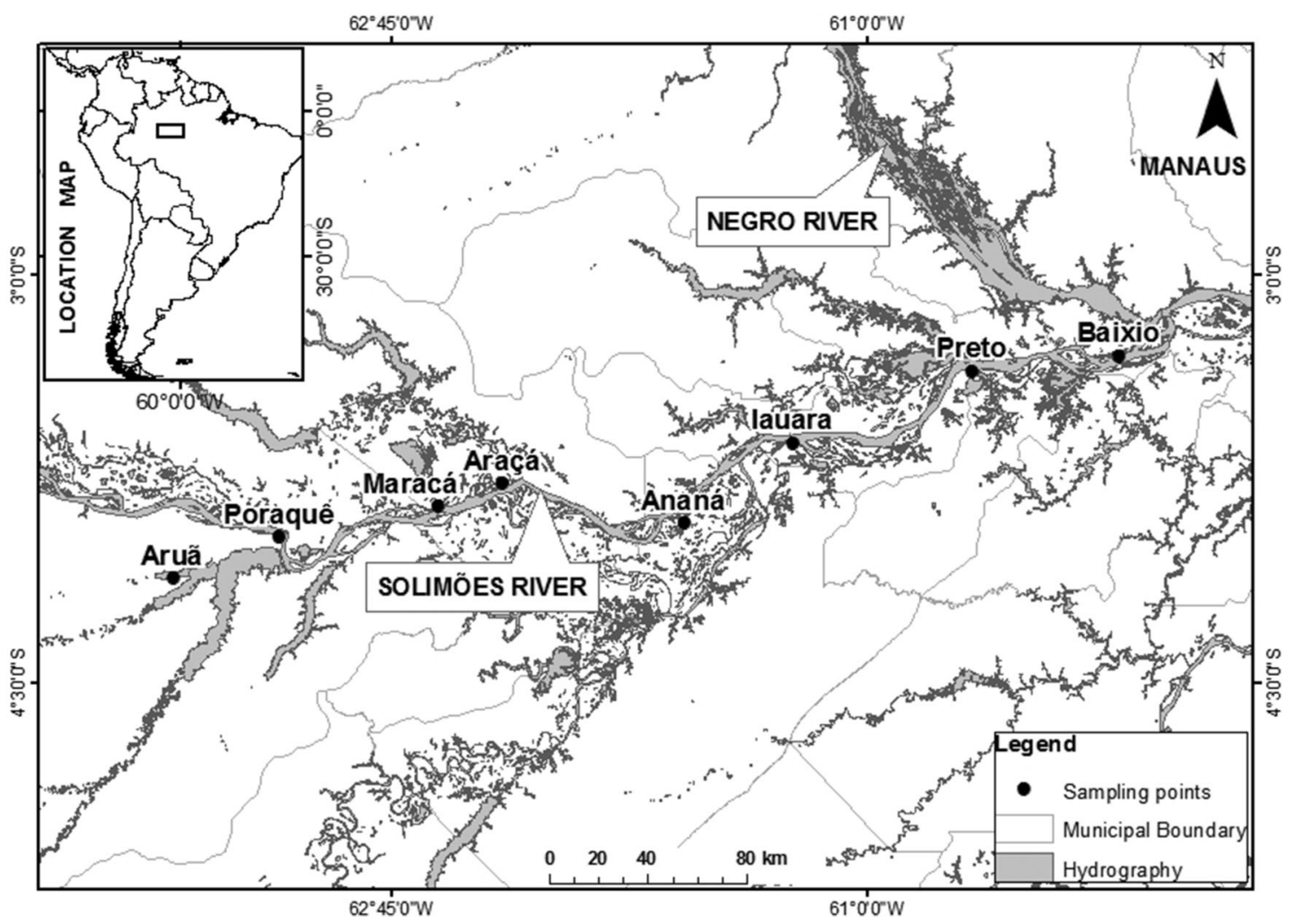

Figure 1. Study area showing the sampled lakes and the stretch of the Rio Solimões. 


\section{Data Sampling and Analysis}

Samples were taken once during each of the four stages of the hydrologic cycle, performed in experimental fisheries with gillnets of standard dimensions ( 20 meters in length by 2 meters height) and different mesh sizes (30, 40, 50, 60, 70, 80, 90, and $100 \mathrm{~mm}$ between opposite knots). To encompass the maximum fish activity periods, the nets were set between 05:00 and 06:00 h (predawn) and brought in with the catch $12 \mathrm{~h}$ later (just after dusk). The sampling efforts were held constant for each lake and sample date. Fish were identified, measured by standard length (centimeters) and total weight (grams), and preserved in formalin $10 \%$ for permanent storage in the Laboratory of Fishery Ecology of the Federal University of Amazonas in Manaus, Brazil.

The parameters $a$ and $b$ from the weight-length relationship were estimated by non-linear estimation using the algorithm of Levenberg-Marquardt (Myers 1990). The relative condition factor $(\mathrm{kn})$ was calculated by the equation $k n=W / W e$, proposed by Le Cren (1951), where $W$ is the total weight of an individual and $W e$ is the mean weight estimated for each length by the equation $W e=a$. $L^{b}$, where $a$ and $b$ are the parameters from the weight-length relationship. The index $\mathrm{kn}$ represents the variability of the condition factor around the mean estimated value. It is independent of fish size and is useful for comparisons between fish of different sizes.

Following Bittencourt \& Amadio (2007), to define the seasons of the hydrological cycle, we clustered the estimated values of $\mathrm{kn}$ into years and seasons of the hydrological cycle to test the hypothesis that inter- and intra-annuals means are similar. Prior to the data analysis, we tested the hypothesis of variance homogeneity. Because this hypothesis was rejected, all data were log-transformed prior the use of a two-way Anova using the year and the hydrologic season as factors. We employed a Tukey's test when the null hypothesis was rejected. All statistical analyses were performed in the $\mathrm{R}$ statistical software package version 2.15.3 (R Core Team 2013).

\section{Results}

We measured 1058 individuals of Potamorhina altamazonica, 635 of Potamorhina latior and 873 of Psectrogaster rutiloides. The mean standard length of $P$. altamazonica was $16.12 \pm 3.21 \mathrm{~cm}$, and the mean weight was $111.32 \pm 64.67 \mathrm{~g}$. Potamorhina latior was slightly smaller, with a mean standard length of $14.80 \pm 2.87 \mathrm{~cm}$ and a mean weight of $68.98 \pm 42.86 \mathrm{~g}$. Psectrogaster rutiloides had the smallest average size, with a mean standard length of $12.88 \pm 2.03 \mathrm{~cm}$ and a mean weight of $64.44 \pm 31.26 \mathrm{~g}$. The relative condition factor ranged from 0.8256 to 1.1552 for $P$. altamazonica, from 0.8637 to 1.3149 for $P$. latior, and from 0.8558 to 1.3830 for $P$. rutiloides (Table 1).

The weight-length relationships were as follows: $W=0.0357$. $L^{2.859}$ with $\mathrm{r}=0.96$ for $P$. altamazonica; $W=0.0100 . L^{3.23}$ with $\mathrm{r}=0.94$ for $P$. latior; and $W=0.0600 . L^{2.71}$ with $\mathrm{r}=0.89$ for $P$. rutiloides (Figure 2).

There were intra- and inter-annual differences in the relative condition factors of Potamorhina altamazonica, Potamorhina latior and Psectrogaster rutiloides, besides noticeable interactions effects between year and season of the hydrological cycle (Table 2). For P. altamazonica, the intra-annual estimates of kn were consistently constant for 2004 and 2006, but there were clear decreases between the seasons of flooding-flood for drying-dry in 2005 (Table 3, Figure 3A). The pattern for $P$. latior is somewhat similar to that of $P$. altamazonica; one marked difference was that the highest values occurred during the flood season, followed by a decrease in the drying and dry seasons; the differences were mainly evident for 2004 and 2005. Nevertheless, there was a marked decline in kn in the dryingdry seasons of 2005, similar to the decrease observed for $P$. altamazonica (Table 3, Figure 3B). In addition to the differences in the intra-annual patterns, it is evident that for both Potamorhina species, increases in the relative condition factors occurred during the drying and dry seasons in 2006 (Figures 3A and 3B). Psectrogaster rutiloides showed a slightly different intra-annual pattern from those of the Potamorhina species, mainly because of the estimates for 2006, when there were higher values during the drying-dry seasons than during the flooding-flood seasons (Table 3, Figure 3C). These three species showed a similar inter-annual pattern of lowest $\mathrm{kn}$ values during the drying and dry seasons of 2005. Potamorhina altamazonica and Psectrogaster rutiloides also exhibited an increase in $\mathrm{kn}$ for these same periods of the following year (Figures 3A and 3C).

\section{Discussion}

The hydrological cycle of large rivers in the Amazon basin is monomodal and predictable, with a flood season between June and July and a dry season near the end of the year (Figure 4).

Table 1. Estimates of relative condition factor for the three Curimatidae species, collected at the Rio Solimões, by year and season of the hydrological cycle.

\begin{tabular}{llllr}
\hline Year & Season & P. altamazonica & P. latior & P. rutiloides \\
\hline 2004 & Flooding & $1.1091 \pm 0.1805$ & $1.1395 \pm 0.1468$ & $1.2351 \pm 0.2193$ \\
& Flood & $0.9702 \pm 0.1354$ & $1.2848 \pm 0.3932$ & $1.3830 \pm 0.2748$ \\
& Drying & $1.1482 \pm 0.0807$ & $1.1852 \pm 0.1943$ & $1.1582 \pm 0.1032$ \\
2005 & Dry & $0.9640 \pm 0.2507$ & $0.9579 \pm 0.1733$ & $1.0680 \pm 0.2058$ \\
& Flooding & $1.0319 \pm 0.1499$ & $1.0963 \pm 0.1524$ & $0.9279 \pm 0.0965$ \\
& Flood & $1.1180 \pm 0.2050$ & $1.3149 \pm 0.2286$ & $1.1379 \pm 0.0882$ \\
2006 & Drying & $0.8256 \pm 0.0937$ & $0.9408 \pm 0.0862$ & $0.8558 \pm 0.0816$ \\
& Dry & $0.8539 \pm 0.0952$ & $0.8637 \pm 0.1394$ & $0.8679 \pm 0.1362$ \\
& Flooding & $0.9697 \pm 0.0977$ & $0.9974 \pm 0.1273$ & $0.9426 \pm 0.0844$ \\
& Flood & $1.0282 \pm 0.0937$ & $1.1356 \pm 0.1899$ & $1.0218 \pm 0.1562$ \\
& Drying & $1.0505 \pm 0.0854$ & $1.2145 \pm 0.1559$ & $1.1706 \pm 0.1392$ \\
& Dry & $1.1552 \pm 0.2240$ & & $1.2010 \pm 0.1403$ \\
\hline
\end{tabular}



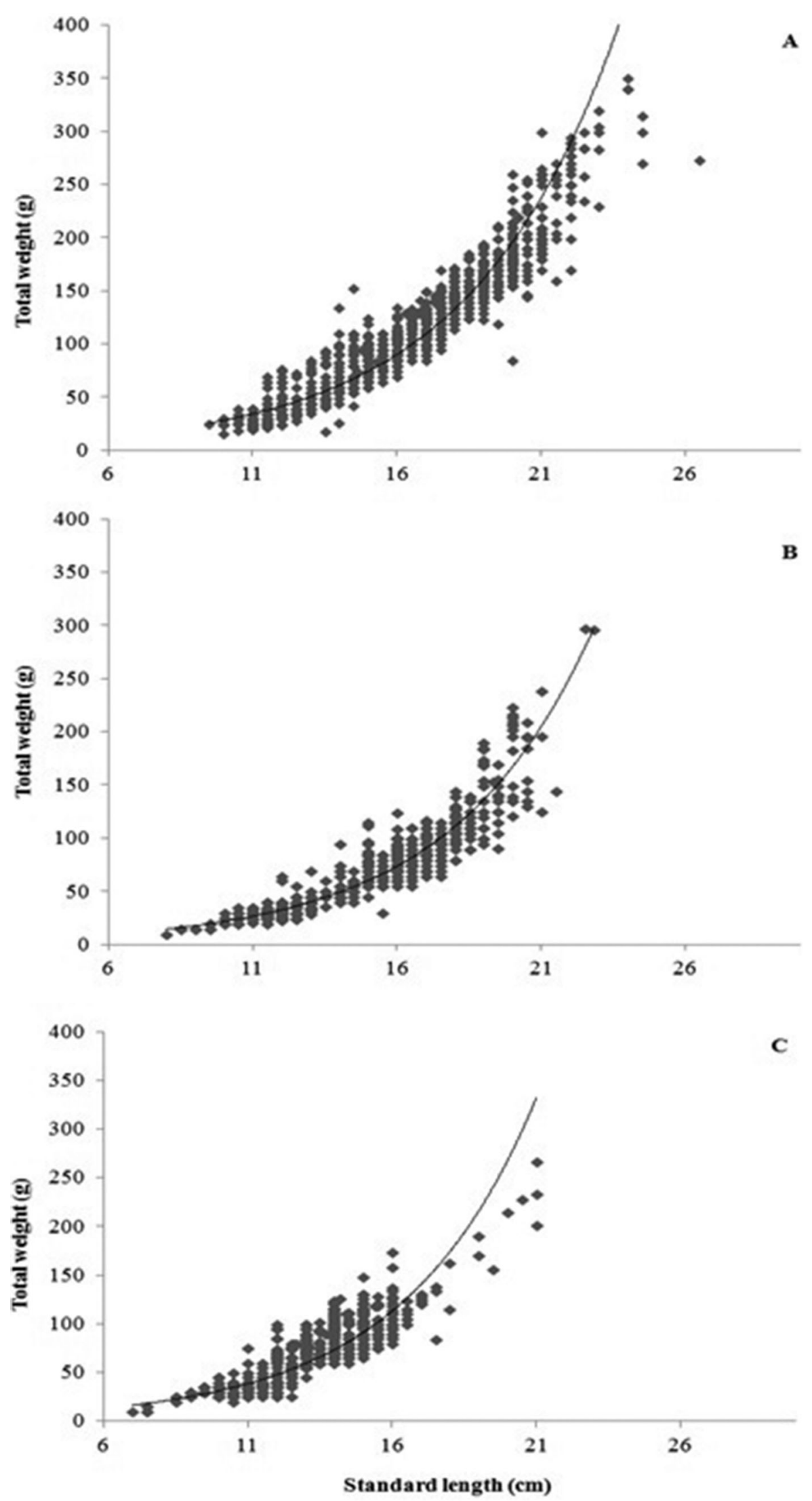

Figure 2. Weight-length relationships estimated for (A) Potamorhina altamazonica, (B) Potamorhina latior and (C) Psectrogaster rutiloides amostrados no rio Solimões. 
Condition factor of Amazonian detritivores fish

Table 2. Summary of intra- and inter-annual two-way Anova applied to data of relative condition factor of Potamorhina altamazonica, Potamorhina latior and Psectrogaster rutiloides.

\begin{tabular}{|c|c|c|c|c|c|c|c|c|c|}
\hline \multirow[t]{2}{*}{ Source of Variation } & \multicolumn{3}{|c|}{ P. altamazonica } & \multicolumn{3}{|c|}{ P. latior } & \multicolumn{3}{|c|}{ P. rutiloides } \\
\hline & $\mathbf{F}$ & df & $\mathbf{p}$ & $\mathbf{F}$ & df & $\mathbf{p}$ & $\mathbf{F}$ & df & $\mathbf{p}$ \\
\hline Season & 12.26 & 3 & $<0.01$ & 22.07 & 3 & $<0.01$ & 8.32 & 3 & $<0.01$ \\
\hline Year & 27.23 & 2 & $<0.01$ & 17.96 & 2 & $<0.01$ & 69.78 & 2 & $<0.01$ \\
\hline Season*Year & 41.11 & 6 & $<0.01$ & 33.05 & 6 & $<0.01$ & 31.99 & 6 & $<0.01$ \\
\hline Error & \multicolumn{3}{|c|}{1046} & \multicolumn{3}{|c|}{623} & \multicolumn{3}{|c|}{861} \\
\hline
\end{tabular}
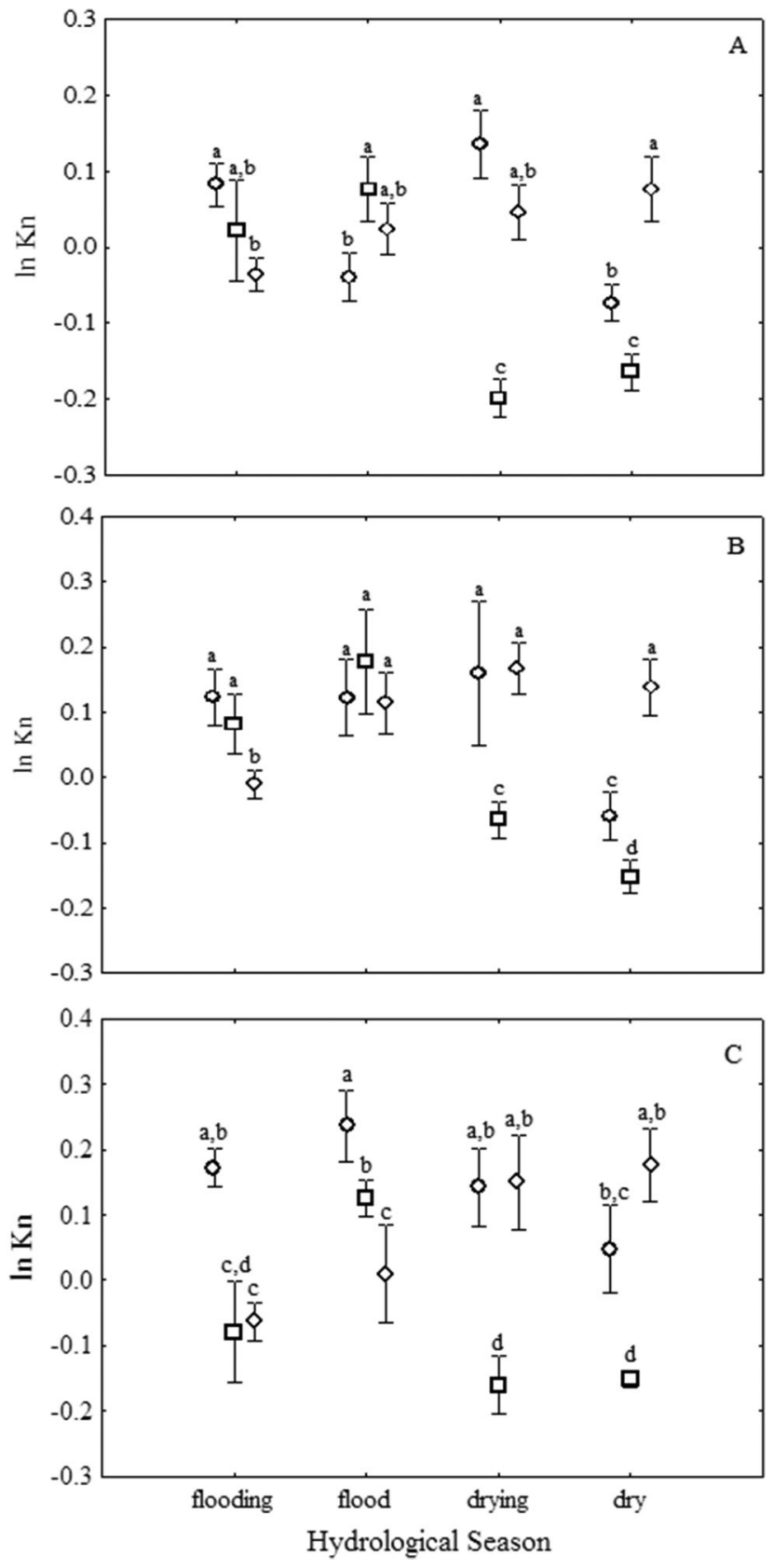

Figure 3. The dynamics of the condition factor during the seasons of the hydrological cycles of 2004 (circle), 2005 (square), and 2006 (triangle) for (A) Potamorhina altamazonica, (B), Potamorhina latior and (C) Psectrogaster rutiloides. Vertical bars denote 0.95 confidence intervals around the mean.
These shifts between high and low water periods represent deep changes in the aquatic environment (Junk et al. 1989), and the resident biota had developed several strategies to survive in this dynamic system. Nevertheless, a low water season is typically an unfavorable period for fishes, mainly for those species that explore flooded forest and other habitats that are specific to the flood seasons.

We hypothesize that the intra-annual differences, observed within each year, in the condition factor are most likely related to food availability. The feeding behaviors of Potamorhina altamazonica, Potamorhina latior, and Psectrogaster rutiloides are characterized by a strong dependence on items, such as detritus, algae, and plankton (Mérona \& Rank de Mérona 2004), which are more abundant during the flooding and flood seasons. Detritus represents an important food source for Amazonian fish and is composed of organic and inorganic material that originates from plants and litter (Fernandes 1997). In addition to habitats that are available during high water periods, such as those containing macrophytes, debris and trees of flooded forest areas can serve as substrates for algae and periphyton (Piedade et al. 2010).

These Curimatidae species undergo lateral migrations during the receding water season, leaving the floodplain lakes toward the river channel during August and September (Fernandes 1997). The stimulus for this migration is not reproductive, unlike the migration that occurs at the beginning of the flooding season, when these species migrate out from the floodplain to breed upriver. The August-September migration is a strategy to avoid the disadvantageous condition of the dry season, although some

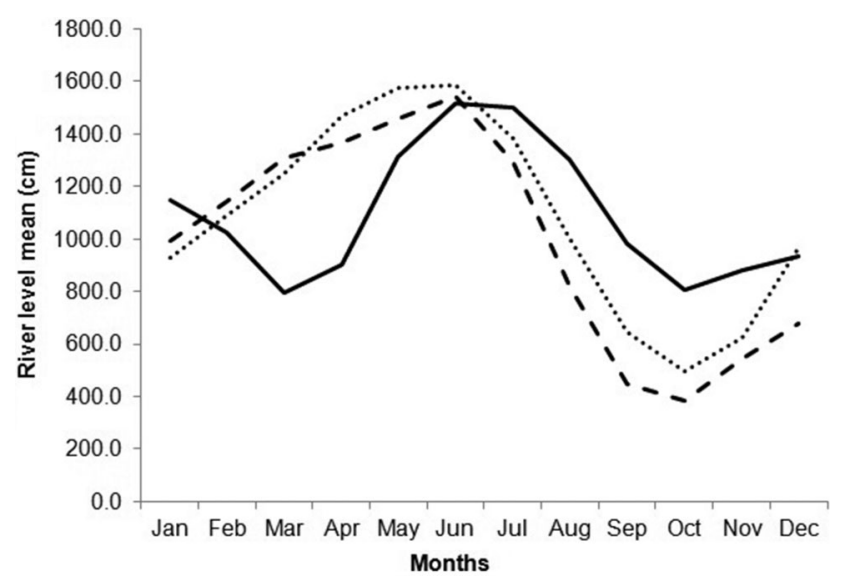

Figure 4. River level (cm) at Coari Station for (- 2004, (- - - ) 2005, and (…...) 2006 (Source: Agência Nacional de Águas - ANA, Coari Station, Code: 13150003). 
same species have developed a physiological resistance to hypoxia (Soares \& Junk 2000; Anjos et al. 2008). The gradual drying of the floodplains increases fish densities and intensifies biotic interactions, mainly predation and competition, because habitat and food resources are declining. The fish that remain in the floodplain lakes during the dry seasons become stranded in isolated pools, where they compete for limited resources and are at risk of being preyed upon by predators, such as piscivorous fish, birds and other vertebrates (Winemiller \& Jepsen 1998).

By contrast, our hypothesis to explain the interaction effects could be associated with climatic events. The main driver of the inter-annual variability of the river level at the Amazon basin is the El Niño-Southern Oscillation (ENSO). Historically, the term "El Niño" has been used to describe the coastal warming of the near-equatorial Pacific Ocean off the coast of Peru (Lehodey et al. 2006). However, the extreme drought that occurred in 2005 (Figure 4) was a result of the summed effects of the ENSO and the warming of the Southeast Atlantic Ocean. This extreme climatic event caused drastic effects on the Amazonian environment (Marengo et al. 2008) and was responsible for the lowest kn values for the second half of 2005 .

The rapid recovery of these species in the year postdrought, with high kn estimates mainly for the second half of the year during the low water seasons could be associated with three non-exclusive phenomena: (i) these species could be identified as r-strategists along the $\mathrm{r}-\mathrm{K}$ continuum for fishes (Jones 1976) or periodic strategists (Winemiller 1992) thus they are able to colonize the newly flooded floodplains immediately after the drought because the river channel can be assumed as source grounds; (ii) the predation rate could be decreased after the drought because potential predators are K-strategists within the same $r-K$ continuum (Jones 1976) or equilibrium strategists in the sense of Winemiller (1992), and their ability to colonize should be decreased compared to Curimatidae species; and (iii) the availability of detritus is increased after the drought because the floodplain environment was enriched/ fertilized after this extreme drought.

Freitas et al. (2013) studied the floodplains assemblages during the same time period of the present study and observed a disproportionate post-drought increase in abundance among fish species that develop annual migrations as part of their life cycles. These species are more resistant to extreme drought because they can explore other perennial environments. Another possible explanation is what is termed the fertilizer hypothesis. We are in agreement with Freitas et al. (2013), that the increased levels of algivore and detritivore species might be an indication that the abundance of fish carcasses and growth of terrestrial plants on exposed soil during extended low water periods provide elevated nutrient levels in returning flood waters, which benefit fish that feed on algae or decomposing vegetation. This type of nutrient enrichment should affect other biotic interactions, including changes in the normal intensity of predatorprey relationships (Davis et al. 2010).

\section{Acknowledgments}

We thank I. Santos, W. Dias, and J. Pena for help in field work. The research was supported by grants 0.1.04.0567.00 and 0.1.06.1223.00 from PIATAM Project, funded by FINEP, and by grants 023/2009 - PRONEX/FAPEAM-CNPq and 563073/ 2010-1 - CNPq.

\section{References}

ANJOS, M.B., OLIVEIRA, R.R. \& ZUANON, J.A.S. 2008. Hypoxic environments as refuge against predatory fish in the Amazonian floodplains. Braz J Biol 68:45-50, http://dx.doi.org/10.1590/S151969842008000100007.

ARAÚJO-LIMA, C.A.R.M. 1991. A larva da branquinha comum Potamorhina latior (Curimatidae, Pisces) da Amazônia. Rev B Biol 51:45-56.

ARAÚJO-LIMA, C.A.R.M. \& RUFFINO, M.L. 2003. Migratory fishes of the Brazilian Amazon. Pp. 233-302. In Migratory Fishes of South America: Biology, Fisheries and Conservation Status (J. Carosfeld, B. Harvey, C. Ross \& A. Baer, eds.). The World Bank press, Otawa, p. 233-302.

BITTENCOURT, M.M. \& AMADIO, S.A. 2007. Proposta para identificação rápida dos períodos hidrológicos em áreas de várzea do rio Solimões-Amazonas nas proximidades de Manaus. Acta Amaz 37:303-308, http://dx.doi.org/10.1590/S0044-59672007000200019.

DAVIS, J.M., ROSEMOND, A.D., EGGERT, S.L., CROSS, W.F. \& WALLACE, J.B. 2010. Long-term nutrient enrichment decouples predator and prey production. P Natl Acad Sci USA 107: 121-126, http://dx.doi.org/10.1073/pnas.0908497107.

FERNANDES, C.C. 1997. Lateral migration of fishes in Amazon floodplains. Ecol Freshw Fish 6:36-44, http://dx.doi.org/10.1111/ j.1600-0633.1997.tb00140.x.

FICKE, A.D., MYRICK, C.A. \& HANSEN, L.J. 2007. Potential impacts of climate changes on freshwater fisheries. Rev Fish Biol Fisher 17:581-613, http://dx.doi.org/10.1007/s11160-007-9059-5.

FREITAS, C.E.C., SIQUEIRA-SOUZA, F.K., HUMSTON, R. \& HURD, L.E. 2013. An initial assessment of drought sensitivity in Amazonian fish commnunities. Hydrobiologia 705:159-171, http://dx.doi.org/10.1007/s10750-012-1394-4.

FREITAS, C.E.C., RIVAS, A.A.F., CAMPOS, C.P., SANT'ANNA, I.R., KAHN, J.R., CORREA, M.A.A. \& CATARINO, M.F. 2012. The potential impacts of global climatic changes and dams on Amazonian fish and their fisheries. In New Advances and Contributions to Fish Biology (Türker, H. ed.). INTECH, Croatia, p. $175-196$

FROESE, R. 2006. Cube law, condition factor and weight-length relationships: history, meta-analysis and recommendations. J Appl Ichthyol 22:241-253, http://dx.doi.org/10.1111/j.1439-0426.2006.00805.x.

GARCEZ, R.S. \& FREITAS, C.E.C. 2008. The influence of flood pulse on fish communities of floodplain canals in the Middle Solimões River. Neotrop Ichthyol 38:34-49.

GRANADO-LORENCIO, C., ARAÚJO-LIMA, C.A.R.M. \& LOBÓN-CERVIÁ, J. 2005. Abundance-distribution relationship in fish assembly of Amazonas floodplain lakes. Ecography 28:515520, http://dx.doi.org/10.1111/j.0906-7590.2005.04176.x.

JONES, J.M. 1976. The r-K-Selection Continuum. Am Nat 110:320323, http://dx.doi.org/10.1086/283069.

JUNK, W.J., BAYLEY, P.B. \& SPARKS, R.E. 1989. The flood pulse concept in river-floodplain systems. Can Spec Pub Fisher Aquat Sci 106:110-127.

JUNK, W.J., SOARES, G.M. \& SAINT-PAUL, U. 1997. The fish. In The central Amazon floodplain. Ecology of a pulsing system (Junk, W.J. ed.). Ecological studies 126. Spring-Verlag, Berlin, p. 385-408, http://dx.doi.org/10.1007/978-3-662-03416-3.

LE CREN, E.D. 1951. The length-weight relationship amd seasonal cycle in gonad weight and condition in the perch (Perca fluviatilis). J Anim Ecol 20:201-219, http://dx.doi.org/10.2307/1540.

LEHODEY, P., ALHEIT, J., BARANGE, M., BAUMGARTNER, T., BEAUGRAND, G., DRINKWATER, K., FROMETIN, J.M., HARE, S.R., OTTERSEN, G., PERRY, R.I., ROY, C., van der LINGEN, C.D \& WERNER, F. 2006. Climate variability, fish, and fisheries. J Climate (Special Edition) 19:5009-5030.

LIMA, A.C. \& ARAÚJO-LIMA, C.A.R.M. 2004. The distributions of larval and juvenile fishes in Amazonian rivers of different nutrient 
status. Freshwater Biol 49:787-800, http://dx.doi.org/10.1111/j.13652427.2004.01228.x.

MARENGO J.A., NOBRE, C.A., TOMASELLA J., OYAMA, M.D., OLIVEIRA, G.S., OLIVEIRA, R., CAMARGO, H., ALVEZ, L.M. \& BROWN, I.F. 2008. The drought of Amazonia in 2005. J Climatol 21:495-506, http://dx.doi.org/10.1175/2007JCLI1600.1.

MÉRONA, B. \& RANKIN-DE-MÉRONA, J. 2004. Food resource partitioning in a fish community of the Central Amazon Floodplain. Neotrop Icthyol 2:75-84.

MYERS, J.H. 1990. Population cycles of western tent caterpillars: experimental introductions and synchrony of fluctuations. Ecology 71:986-995, http://dx.doi.org/10.2307/1937367.

PIEDADE, M.T.F., FERREIRA, C.S. \& FRANCO, A.C. 2010. Estrategias reproductivas de la vegetación y sus respuestas al pulso de la inundación en las zonas inundables de la Amazonía Central. Eco 19: 52-66.

POUILLY, M., YUNOKI, T., C. Rosales \& L. Torres. 2004. Trophic structure of fish assemblages from Mamoré River floodplain lakes (Bolivia). Ecol Freshw Fish 13:245-257, http://dx.doi.org/10.1111/ j.1600-0633.2004.00055.x.

R CORE TEAM. 2013. R: A language and environment for statistical computing. R Foundation for Statistical Computing, Vienna, Austria. ISBN 3-900051-07-0, URL http://www.R-project.org/.

REIS, R.E., KULLANDER, S.O. \& FERRARIS, C.J. 2003. Check List of the Freshwater Fishes of South and Central America. EDIPUCRS. Porto Alegre. 742p.

SAINT-PAUL, U., ZUANON, J.L.A., CORREA, M.A.V., GARCIA, M., FABRÉ, N.N., BERGER, U. \& JUNK, W.J. 2000. Fish communities in central Amazonian white and blackwater floodplains. Environ Biol Fish 57:235-250, http://dx.doi.org/10.1023/ A:1007699130333.
SIQUEIRA-SOUZA, F.K. \& FREITAS, C.E.C. 2004. Fish diversity of floodplain lakes on the lower stretch of the Solimões River. Braz J Biol 64:501-510.

SOARES, M.G.M. \& JUNK, W.J. 2000. Respiratory adaptations of five curimatids species (Teleostei, Curimatidae) to oxygen depletion in an Amazonian Floodplain lake. Verh Int Ver für Theor Angew Limnol 27:1063-1069.

SOARES, M.G.M., MENEZES, N. \& JUNK, W.J. 2006. Adaptations of fish species to oxygen depletion in a central Amazonian floodplain lake. Hydrobiologia 568: 353-367, http://dx.doi.org/10.1007/ s10750-006-0207-z.

TEJERINA-GARRO, F.L., FORTIN, R. \& RODRIGUEZ, M.A. 1998 Fish community structure in relation to environmental variation in floodplain lakes of the Araguaia River, Amazon Basin. Environ Biol Fish 51: 399-410, http://dx.doi.org/10.1023/A:1007401714671.

VAL, A.L. \& ALMEIDA-VAL, V.M.F. 1995. Fishes of the Amazon and their Environment: Physiological and Biochemical Aspects. Springer. Hidelberg.

VARI, R.P. 1984. Systematics of the neotropical Characiform genus Potamorhina (Pisces, Characiformes). Smithsonian Cont Zool 400:36 p.

VARI, R.P. 1992. Systematics of the neotropical characiform genus Curimatella Eigenmann and Eigenmann (Pisces: Ostariophysi), with summary comments on the Curimatidae. Smithsonian Cont Zool 533:48 p.

WINEMILLER, K.O. 1992. Life history strategies and the effectiveness of sexual selection. Oikos 62:318-327, http://dx.doi.org/ $10.2307 / 3545395$.

WINEMILLER, K.O. \& JEPSEN, D.B. 1998. Effects of seasonality and fish movements on tropical river food webs. J Fish Biol 53(Supplement A):267-296, http://dx.doi.org/10.1111/j.1095-8649. 1998.tb01032.x. 